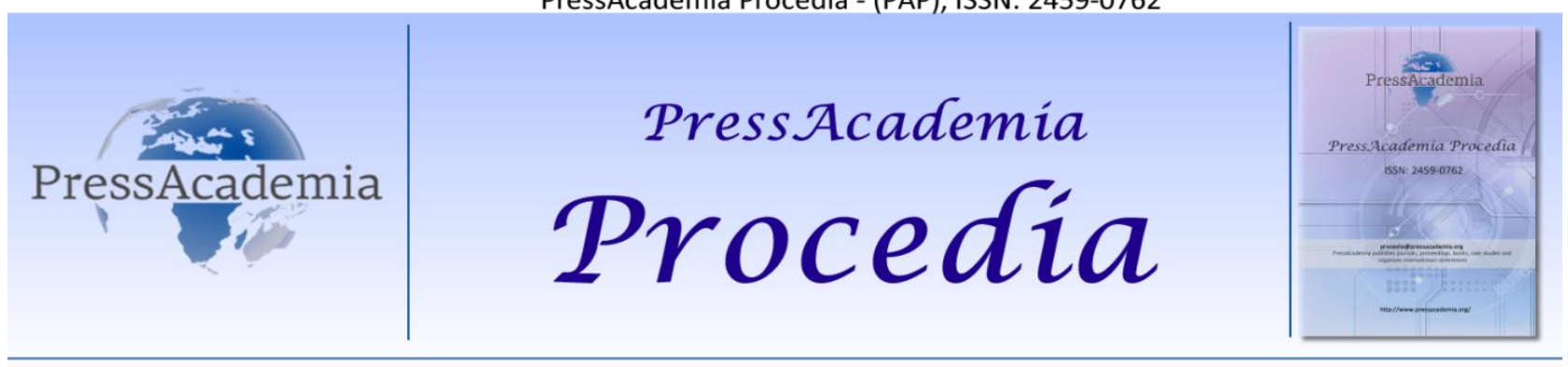

2nd World Conference on Technology, Innovation and Entrepreneurship

May 12-14, 2017, Istanbul, Turkey. Edited by Sefer Şener

\title{
COMPETITION POLICY AND ITS IMPORTANCE FOR THE ECONOMY
}

\author{
DOI: 10.17261/Pressacademia.2017.562 \\ PAP-WCTIE-V.4-2017(54)-p.418-421
}

Nika Asanidze

Tbilisi State University. nikaasanidze@gmail.com

\begin{abstract}
The article analyzes and discusses topics such as competitition and it's importance for markets. Competition is a cornerstone of our economic and social order. The fact that competition leads to the best overall economic results is now undisputed in most economies around the world. Effective competition encourages businesses to push forward. They must make an effort to win customers. As a consequence, consumers can benefit directly from better quality at lower prices. Competition Agencies increased the effectiveness of their cartel prosecution efforts, for example by establishing specialized anti-cartel divisions, revising their leniency programme and lauchinannonymous whistle-blowing system. High-level fines can only gave a deterrent effect if the cartel members have reason to expect that their cartel activities will be uncovered. The leniency programme as one of the sources available for uncovering anti-competitive agreements this also has a strong deterrent effect. Cartel members must expect at all time that one of them might have reported the illegal agreements to the competition authorities. The prosecution of illegal hardcore cartels ${ }^{1}$ is of key relevance for effective competition protection and, as such, has a direct positive effect in the economy and costumers. Cartels cause great harm to the economy because they lead to higher prices, lower product quality and less innovation. This harm can only be prevented if cartels are effectively prosecuted. Also, anti-competitive agreements lead to excessive prices coupled with inferior product quality. At the same time the elimination of competition undermines the innovative power of businesses.Cartels thus hurt the economy as a whole and the consumer in particular. The motivation to study competition policy and its importance for economy is step to introduce more economic possibilities and partnerships in our developing world.
\end{abstract}

Keywords: Competition policy, economic order, social order JEL Codes: D83, N75

\section{INTRODUCTION}

Competition puts businesses under constant pressure to offer the best possible range of goods at the best possible prices, because if they don't, consumers have the choice to buy elsewhere. In a free market ${ }^{2}$, business should be a competitive game with consumers as the beneficiaries. Many developing countries now prioritize growth in their national poverty reduction strategies. Because effective competition is a driver of productivity, competition policy should be an essential component of any pro-poor growth strategy, Crucially, competition facukutates greater equality of opportunity by breaking down the barriers to fair competition that often help to protect incumbent elites. Competition policy is about applying rules to make sure businesses and companies compete fairly with each other. This encourages enterprise and efficiency, creates a wider choice for consumers and helps reduce prices and improve quality.

\footnotetext{
${ }^{1}$ Cartels-price,quota,customer allocation and territorial agreements.

${ }^{2}$ free market is a system in which the prices for goods and services are determined by the open market and consumers, in which the laws and forces of supply and demand are free from any intervention by a government, price-setting monopoly, or other authority. Another view considers systems with significant market power, inequality of bargaining power, or information asymmetry to be less than free.
} 
Low prices for all: the simplest way for a company to gain a high market share is to offer a better price. In a competitive market, prices are pushed down. Not only is this good for consumers - when more people can afford to buy products, it encourages businesses to produce and boosts the economy in general. Better quality: Competition also encourages businesses to improve the quality of goods and services they sell - to attract more customers and expand market share. Quality can mean various things: products that last longer or work better, better after-sales or technical support or friendlier and better service. More choice: In a competitive market, businesses will try to make their products different from the rest. This results in greater choice - so consumers can select the product that offers the right balance between price and quality. Innovation: To deliver this choice, and produce better products, businesses need to be innovative - in their product concepts, design, production techniques, services etc. Better competitors in global markets: Competition within the EU helps make European companies stronger outside the EU too - and able to hold their own against global competitors.

The main aims of competition policy are to promote competition; make markets work better and contribute towards improved efficiency in individual markets and enhanced competitiveness.Competition policy aims to ensure:

- Technological innovation which promotes dynamic efficiency in different markets

- $\quad$ Effective price competition between suppliers

- Safeguard and promote the interests of consumers through increased choice and lower price levels

There are four key pillars of competition policy in the European Union:

1. Antitrust \& cartels: This involves the elimination of agreements that restrict competition including price-fixing and other abuses by firms who hold a dominant market position (defined as having a market share in excess of forty per cent)

2. Market liberalisation: Liberalisation involves introducing competition in previously monopolistic sectors such as energy supply, retail banking, postal services, mobile telecommunications and air transport

3. State aid control: Competition policy analyses state aid measures such as airline subsidies to ensure that such measures do not distort the level of competition in the Single Market

4. Merger control: This involves the investigation of mergers and take-overs between firms (e.g. a merger between two large groups which would result in their dominating the market)

\section{COMPETITION SUPPORTS ECONOMIC GROWTH}

Competition supports international competitiveness in two ways. The first and most visible effect is by keeping domestic prices down and by providing a greater choice and quality of goods and services. This means that companies can keep their costs down and produce cheaper, better products that can be more easily exported. Competition also drives productivity growth as firms continually strive to improve processes, reduce costs and produce products better suited to evolving consumer needs.

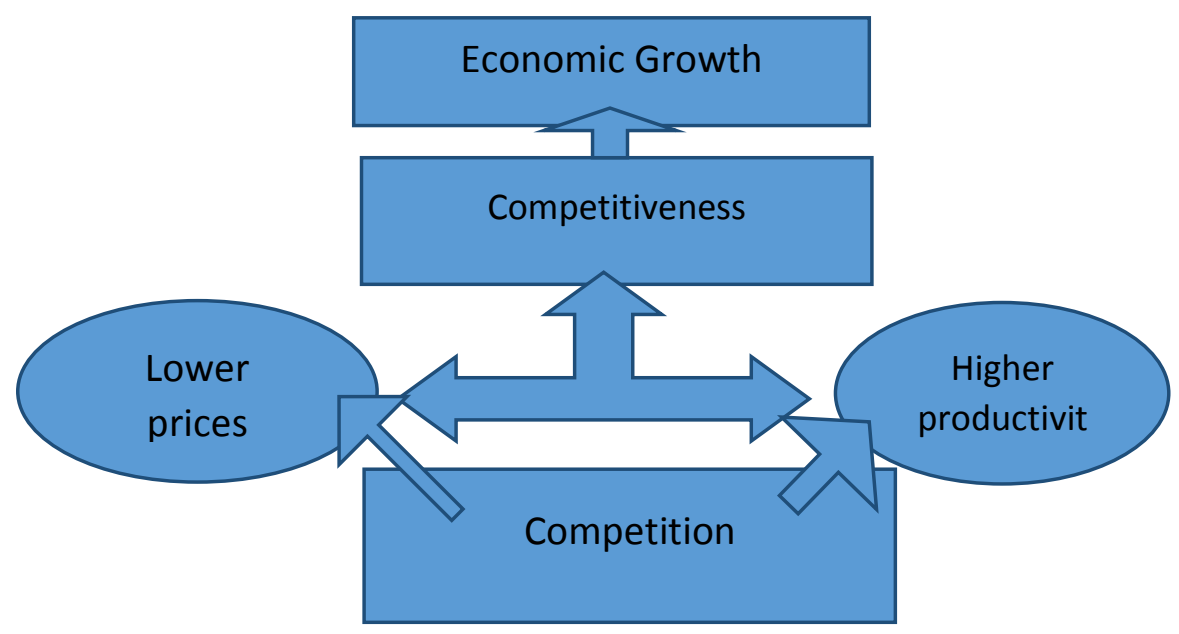


To increase productivity, that is, to get more output from a given level of inputs, a business must become more efficient. It must also innovate and develop new and highly sought after products that consumers want. Productivity is a measure of the level of value a business gets from its inputs. Where competition is strong, productivity is strong. If companies operating in competitive markets do not improve their productivity performance they will lose customers. Competition is the critical driver of performance and innovation. It benefits everyone by enabling us to choose from an array of excellent products at affordable prices. Competition also encourages the adoption of innovation as companies evolve and new ideas flourish in the marketplace. Competition is very important for developing and small countries, as Georgia ${ }^{3}$.

\section{ABOUT THE LENIENCY POLICY}

In cases of anti-competitive agreements (in contrast to most offences such as theft, criminal damage to property or bodily injury, it is not only unclear who committed an infringement. Even the fact that an infringement has taken place is initially unknown. Illegal cartel agreements are conducted in secret. There is a high level of conspiracy: The cartel members rarely produce written documents and try to hide possible evidence or destroy evidence at an early stage. In the eyes of outside observers the result of anti-competitive agreements, for example excessive prices, could have many other causes. As a consequence, it is usually a big challenge for competition authorities to discover an infringement at all, let alone secure sufficient evidence to prove the illegal cartel agreement and impose a fine. After all, the administrative order imposing the fine needs to withstand judicial review. In order to effectively combat cartels it is often necessary to uncover cartel agreements with the help of an insider. It is therefore essential to induce cartel members to cooperate with the competition authority. The leniency programme is applicable to all participants in a cartel, natural persons as well as companies. It clearly distinguishes between immunity from and reduction of a fine. Only the first applicant will be granted immunity from a fine, later applications can only lead to reductions of a fine of up to 50\%: The first applicant to disclose information and evidence giving rise to the initial suspicion of a hardcore cartel will be automatically granted immunity from a fine. This provision only applies if the applicant cooperates fully and on a continuous basis with the agency, and was neither the only ringleader of the cartel nor coerced others to participate in it. If the first applicant only comes forward after the agency has already formed an initial suspicion, he/she will have to do more to be granted immunity.

All other applicants who cannot be granted immunity can have their fines reduced by a maximum of $50 \%$, provided they cooperate fully and continuously with the agency. The amount of the reduction granted depends on the value of the cooperation and the order of precedence of the application in the leniency queue. The leniency programme is only applicable in cases of horizontal agreements and coordination between competitors. For other infringements of competition law, for example violation of the prohibition of vertical price fixing, the cooperation provided by applicants can, however, also be taken into account as a mitigating factor in the calculation of the fines. One objective of the leniency programme is to make it as easy as possible for cartel members to cooperate with the agencies. An application can therefore also be filed verbally and/or in English. The applicants' position in the leniency queue is decisive for their immunity from fines or the amount of reduction of their fines. However, cartel members often do not have immediately available the extensive information required for a leniency application. With its 'marker' system the leniency programme offers the possibility to secure a position in the queue for a certain amount of time. Applicants declare their willingness to cooperate with the agency and indicate the type and duration of the infringement, the product and geographic markets affected as well as the identity of the cartel members. In addition, a marker application must state at which other competition authorities applications have been or will be filed. The applicant then receives a confirmation of receipt and has a maximum of 8 weeks to draft a complete leniency application. If the application is filed within this period, the position in the leniency queue is safeguarded and other leniency applications filed in the meantime move down in the queue.

\section{THE ROLE OF A COMPETITION AGENCY}

Competition contributes to growth in many ways. For example: there is evidence that it reduces inflation rates, both at the sectoral and aggregate level ${ }^{4}$. And it is a defence against the entrenchment of vested interests and protectionism, opening up markets to new entrants and increasing the attractiveness of a country as a recipient of foreign direct investment. The role of competition in driving economic growth is especially important in the current economic climate. With macroeconomic tools likely to prove insufficient, and their use restricted by the need for fiscal consolidation, microeconomic instruments (such as the

\footnotetext{
${ }^{3}$ is a country in the Caucasus region of Eurasia. Located at the crossroads of Western Asia and Eastern Europe

${ }^{4}$ European Central Bank (2005), Does Product Market Competition Reduce Inflation? shows a robust and significant negative link between competition and inflation, both at the aggregate and sectoral levels.
} 
removal of unnecessary regulatory burdens and the protection and promotion of competition) become all the more important. This is a message echoed by many commentators, including those from outside the competition regime. To fulfil its potential to contribute to economic growth. An effective competition policy needs to address both public and private restrictions on competition. The restrictions on competition that can result from the actions of private agents - for example the creation of price-fixing cartels or abuse of market power by dominant firms - and the impact that they can have on efficiency and innovation are well known.

But it is also essential to recognise that governments can also have an adverse impact on competition, and as a result, the growth of a particular public sector. This can occur through overt actions, such as exempting certain sectors from the application of competition laws or granting subsidies to industries or individual players. It can also occur through more subtle forms of market intervention (for instance, by introducing regulations that, while aiming to achieve public policy objectives, provide an advantage to incumbents). That is not to say that governments do not have a role to play in markets - in many cases, the role of government is a legitimate and necessary one - as markets cannot exist without a framework of rules. Markets, left to their own devices, can also fail because of market power, information asymmetries or externalities.

However, government interventions can have unforeseen, yet significant consequences. As such, the full cost of intervention needs to be carefully assessed before deciding whether, how much, and how to intervene - especially as over-intervention, not under-intervention is usually the bigger risk. In this respect, competition agencies have an important role to play in the sometimes difficult task of helping policymakers consider all costs and benefits of a market intervention. This is essential for a number of reasons. First, there might be a bias in evidence. The benefits of government interventions might be easier to see than the cost of lost competition, especially as much of the evidence is likely to come from interest groups (which have the most to lose) and might be weighed in a certain direction.

Second, governments need to factor in (but frequently overlook) the benefits of dynamic efficiency, and the risks derived from preserving business models that are unsustainable, while blocking innovation and new entrants to the market. These benefits, while potentially significant, can be difficult to assess or rely on in advance and may take years to materialise.

\section{CONCLUSION}

In conclusion, competition policy plays a key role in fostering dynamic markets and in stimulating economic growth. The international competitiveness of industries depends on access to inexpensive inputs, improvements in efficiency and productivity and innovation, all of which competition promotes. Competition is central to the operation of markets, and fosters innovation, productivity and growth, all of which create wealth and reduce poverty. However, markets do not always work well, and uncompetitive markets are often those that matter most for the poor. This paper outlines the direct and indirect, and often complex, linkages between competition and competition policy. The existence and importance of these linkages is still not sufficiently recognised in the developing world.

\section{REFERENCES}

OECD, Guide for helping competition authorities assess the expected impact of their activities, April 2014 (available at: www.oecd.org/competition/guide-impact-assessment-competition-activities.htm)

The ECN Leniency Programme is available here: http://ec.europa.eu/competition/ecn/mlp revised 2012 en.pdf

https://www.westeastinstitute.com/wp-content/uploads/2016/12/Giorgi-Benashvili-Nika-Asanidze.pdf

Connor, John M., Global Price Fixing, Berlin 2008, p. 338.

Cf. Council Regulation (EC) No 1/2003 of 16 December 2002 on the implementation of the rules on competition laid down in Articles 81 and 82 of the Treaty, Official Journal L $1 / 1$ of 4 January 2003.

Competition and growth: how can government policy help?' - http://www.oft.gov.uk/news-and-updates/speeches/2011/1511

Laitenberger, Ulrich and Smuda, Florian (2015): Estimating Consumer Damages in Cartel Cases, Journal of Competition Law \& Economics 11 (4), 955-973.

Nickell (1996), ' Competition and Corporate Performance', Journal of Political Economy

OECD (2007a), 'Competition Assessment Toolkit', www.oecd.org/dataoecd/15/59/39679833.pdf 